såvel de materielle strukturer og rumformer der omgiver individerne, som det intellektuelle og æstetiske beredskab hvormed vi opfatter og forstår disse strukturer og rumformer.

Udover at Gotbic Architecture and Scholasticism præsenteres for første gang på dansk og at vi får en god introduktion til såvel Panofsky som Bourdieu - fint skrevet af Lise Bek og Vagn Lyhne - får vi altså præsenteret en finurlig sammenhæng mellem to så tilsyneladende forskellige områder som middelalder-arkitekturteori og moderne sociologi. Læseren får med andre ord indsigt $\mathrm{i}$ spændvidden $\mathrm{i}$ traditionens elaborering af habitusbegrebet, samt indblik i selve 'the making of Bourdieus i dag så udbredte $o g$ anerkendte feltteori. For dette kan vi takke redaktøren Vagn Lyhne, der også tidligere har glimret med den velkomponerede antologi Tankebygninger (1994). Gotik-arkitektur-skolastik-habitus henvender sig både til den alment interesserede læser, og den læser der arbejder specifikt med arkitektur- og rumanalyse i et sociologisk perspektiv. Bogen fortjener de bedste anbefalinger.

\section{Hvem er Bendt Bendtsen?}

Anders Eblers Dam (red.), Forandre for

at bevare? -tanker om konservatisme, Gyldendal, Kobenhavn, 2003, 288 sider, $248 \mathrm{kr}$.

For nylig blev en række danskere spurgt om de konservative ministres partitilhørsforhold, og man kan roligt sige at genkendelsen ikke var stor. Det konservative folkeparti er simpelthen blevet klemt og glemt. Og sådan er billedet generelt i Europa. De kongeblå konservative er blevet afløst og overhalet af de lyseblå liberale.

I antologien Forandre for at bevare bliver de konservatives politiske situation tydelig. Dels spørger redaktøren, ph.d.-stipendiat Anders Ehlers Dam: "Eksisterer der i dag en diskrepans mellem de Konservative og det konservative?" (s.9-10) Som jeg vil vise nedenfor, svarer bidragene ikke herpå. Og her ligger netop de konservatives problem. En antologi om konservatismen finder ikke partiet interessant nok at beskæftige sig med, hvis man ser bort fra et par enkelte henkastede bemærkninger. Ingen tidligere eller nuværende konservative ministre eller MF'ere har bidraget og det eneste bidrag, der foregiver at have et politisk perspektiv, kommer fra den tidligere redaktør på avisen Dagen (der ikke forstod hverken at forandre eller bevare), Kresten Schultz Jørgensen, der efter en overfladisk tomgang omkring globalisering og netværkssamfund foregiver at skulle give en 'skitse 
til en dynamisk konservatisme', som det hedder i undertitlen. Man læser igennem fortygget snak om den grænseløse tidsalder og er spændt på nytænkningen, der skuffende viser sig at være en 'pragmatisk mellemvej, hvis eneste indhold (og knap det) er, at "anerkende, at identiteter faktisk ikke er til at komme udenom, heller ikke $i$ et moderne og fragmentarisk Danmark, og at det derfor gælder om at formulere fremadrettede (ikke bagudrettede) og inklusive (ikke eksklusive) identiteter." (s.279) Er det alt? Er det en dynamisk konservatisme? Bendt Bendtsen har så sandelig levet forgæves (som partileder). Sidste mand lukker og slukker.

Heldigvis er det ikke alt, hverken i antologien eller i konservatismen. Men symptomatisk er det, at stort set alle bidragsyderne præsenterer en afpolitiseret konservatisme; en værdi- eller kulturkonservatisme. Det er 'den konservative erfaring' (Mads Storgaard Jensen) og 'den konservative eksistens' (Søren Krarup), der er i fokus. Og samlet set er det en vellykket antologi, der forstår at sige meget (og godt) om konservatismen. Et fælles problem som med de fleste politiske ideologier er manglen på en definition af konservatismen, der kan dække de mange retninger, personer og positioner, der behandles under det samme navn.

Den svenske sociolog, Göran Dahl, opstiller til slut i sit bidrag 'Konservatisme -en kort historisk skitse' fem fællestræk ved konservatismens for- skellige retninger: respekt for tradition, understregning af menneskelig ufuldkommenhed og skrøbelighed, det organiske, autoritet og hierarki som en orden givet af gud og/eller naturen samt retten til ens ejendom (s.31-2). Problemet er, at en række af de retninger han selv behandler, er indifferente overfor eller direkte $i$ modsætning til et eller flere af de fem fællestræk. Så forvirringen består.

Så har den ligeledes svenske sociolog, Carl-Göran Heidegren, mere held med i sit bidrag 'Den konservative - om konservatismens etos. Et forsøg' at forsøge at indfange den konservative grundholdning: "For den konservative er mennesket desuden mere sine tilfældigheder end sine valg, dvs. hvad mennesket er, har det $i$ højere grad lykkelige og ulykkelige omstændigheder at takke for end sine egne valg." (s.41) Hermed har han på smuk vis defineret den konservatives opposition til liberale og socialister, der opskriver valgets betydning og mulighed, samtidig med at de anser det at være underlagt tilfældigheder som en hån imod menneskelig skaberkraft. For den konservative er det et menneskeligt vilkår, der skaber kollektiv og individuel selverkendelse omkring det muliges snævre grænser. Heraf stammer det anti-utopiske i konservatismen, som de fleste bidragydere nævner som grundlæggende.

Også Henrik Stampe Lund ('Konservativ fascination - om Botho Strauss') og Kasper Støvring ('Et 
sjælenes frostklima - aspekter af konservativ æstetik') er små perler i afdækningen af den konservatives forholden sig til verden. Adam Holm (samt Stampe Lund, Dahl og Frederik Stjernfelt) tager 'den konservative revolution' under behandling. En retning, der har fået sit eget liv i den akademiske verden helt uafhængig af dens effekt i resten af samfundet (hvilket jeg selv er med til, hvorfor jeg tillader mig at sige det). Her ser man hos Holm og Stjernfelt endelig ansatser til en kritik af 'Fascismens fascination' hos danske konservative i mellemkrigstiden, som vi har savnet som modvægt til i den danske debat om udemokratiske tendenser på venstrefløjen. Stjernfelt udfolder i sit bidrag 'Livet selv - livsfilosofi og konservatisme' en utrolig spændende diskussion af livsfilosofiens mange grene, der er "den form for filosofi, der hævder at livet har et absolut primat over andre filosofiske emner" (s.238). Diskussionen skæmmes dog lidt af en tendens til at se livsfilosofiske impulser og påvirkninger overalt. Så meget at han konkluderer, at "livsfilosofien har sejret." (s.251). Det er ikke alt, der lugter friskt, der er i live.

Det samme kan man sige om Søren Krarups bidrag, der er et opkog på den artikel, han har skrevet igen og igen de sidste fyrre år. Her er virkelig en mand, der har sparet tid ved indførslen af tekstbehandlingens 'klip'-og-'indsæt'-funktion. Det ville være så utroligt kedeligt, hvis det ikke var så ganske afslørende. Ikke engang hans yndlingshadefigurer har ændret sig. Det er stadig kvindefrigørelsen og Georg Brandes. Man skal ikke tage fejl. Krarup er en klassisk reaktionær patriarkalsk tænker. Det er kvindens syndighed, der lokker manden - og dermed samtidig både mikrokosmos (familien) og makrokosmos (samfundet) i fordærv. Hun bruger sine listige erotiske evner til at underlægge sig den svage lystne mand og forføre ham bort fra den sande konservative og nationalistiske vej (se blot s.168-172) og ud i et antiautoritært syndefald af globalisme og godhedsmageri.

Nu kan man selvfølgelig trække alle pointer for langt, så de slår om i deres modsætning. Det viser Hans-Jørgen Schanz i sit bidrag 'Om tradition - et par bemærkninger til modernitet, modernisme og konservatisme', hvor han tager Oplysningstænkningens traditionshad under kritisk behandling. Det er her væsentligt at skelne imellem traditionskritik og traditionshad. Schanz har en vigtig pointe $i$, at vi ikke er blevet aftraditionaliseret i den forstand, at vi lever uden traditioner. Det er udelukkende deres autoritetsstatus, der har ændret sig. Vi er tilbøjelige til at se traditionskritik, som noget der opstår med og definerer moderniteten. Vi opstiller endda et skel imellem traditionelle og moderne samfund.

Her op imod viser Schanz, at traditionskritikken har lange aner: "Det er lige før, at man kan definere selve den filosofiske tænknings fremkomst 
som en træden ud af traditionen og ind $i$ en problematisering af det foreliggende." (s.119). Hermed starter traditionskritikken med førsokratikerne og Platon. Schanz laver en væsentlig distinktion mellem tradition, der "er levende i kraft af, at den holdes i hævd, og det vil sige at den ikke står til diskussion. Den skal ikke legitimere sig" og institution, der "altid er skabt med henblik på at løse bestemte, afgræenselige opgaver, der er pragmatiske i deres indhold, og som derfor altid i princippet skal kunne vurderes på succes eller fiasko" (hhv. s.117, 118). Platon er i denne optik den første antitraditionalistiske og utopiske tænker, da han ser Staten og selve livet som en institution, der kan og skal planlægges.

Traditionskritikken oplever et tilbagefald med Romerrigets treenighed af tradition, religion og autoritet, der overtages af kristendommen. Angrebet herpå sætter ind med reformationen og den nye naturvidenskab, men som Schanz pointerer: "endnu var der ikke tale om en altomfattende og nærmest hadsk traditionskritik." (s.125) Den opstår med Oplysningstænkningens historiefilosofi i slutningen af det 18. århundrede. Traditioner står $i$ vejen for planlægning. Alt bliver nu historisk, det vil sige muligt materiale for menneskelig skaben. Alt, der blokerer for dette, lægges for had som fordomme, overtro og middelaldermørke.

Og det er denne fordom (!), Schanz og som sådan også konservatismen, argumenterer imod. Vi ønsker slet ikke at leve og kan heller ikke leve i et samfund, der er fuldstændig aftraditionaliseret, fuldstændig moderniseret. Og hvis konservatismen har nogen opgave i dag, er det måske at insistere på dette op imod den neoliberale forandringsiver. Ellers risikerer den at blive reduceret til enten en balsam for forjagede lykkeriddere eller en ammunition for aggressive nationalismer. Og så har konservatismen for alvor udspillet sin rolle. Og hvis man skal tro bidragene i denne antologi, ville det være et stort tab.

Mikkel Thorup

\section{Teknotopia}

Gert Balling (red.). Homo Sapiens 2.0: Nar teknologien kryber ind under huden. Gads Forlag. Kobenhavn 2002. 199 kr. 240 sider. Indbundet.

Hvis du, kære læser, vælger ikke at læse denne bog, så skal du vælge en tilsvarende. Der er ingen vej udenom. Det bliver sværere og sværere at se bort fra videnskab og teknologi, når vi taler om noget så hverdagsagtigt og fortroligt som vores krop. Kemi, genetik og bioteknologi er så indgroet i vores liv, at vi sjældent tænker over det. Vi sluger piller med største selvfølgelighed og mener alle, at organtransplantation er en menneskeret.

Hvis vi vil forstå den verden, vi lever $\mathrm{i}$,og have nogen som helst chance for at påvirke, hvordan den 